\title{
VOCATION OR PROFESSION?
}

\author{
JOSEPH T. SALERNO*
}

Should economics be pursued as a profession or a vocation? Below I argue that this choice of subjective orientation is enormously important, and tends to dictate whether an economist will serve the cause of truth and freedom, or waste his or her talents on convenience, ephemera, and statism.

The New Shorter Oxford English Dictionary gives one definition of «vocation" as «The work or function to which a person is called; a mode of life or employment regarded as requiring dedication». The eminent semanticist S.I. Hayakawa also emphasizes «dedication» as the distinctive feature of a vocation which differentiates it from a profession.

In praxeological terms, a vocation involves what Ludwig von Mises «introversive» labor while a profession involves «extroversive» labor. The essence of introversive labor is work undertaken solely for its own sake and not as a means to a more remote end. Extroversive labor, in contrast, is performed because the individual «prefers the proceeds he can earn by working to the disutility of labor and the pleasure of leisure».

One of the «two most conspicuous examples» of introversive labor, according to Mises, is «the search for truth and knowledge pursued for its own sake and not as a means of improving

* Professor of Economics, Pace University. 
one's own efficiency and skill in the performance of other kinds of labor aiming at other ends». The second is "genuine sport, practiced without any design for reward and social success».

It is not that the effort expended by the «truth seeker» or «mountain climber» does not involve the disutility of labor, rather «it is precisely overcoming the disutility of labor that satisfies him». Thus genuine truth seeking in any scientific discipline qualifies economically as «consumption» and its pursuit as a vocation.

The pursuit of almost any vocation, says Mises, requires «not only the personal efforts of the individuals concerned, but also the expenditure of material factors of production and the produce of other peoples' extroversive [...] labor that must be bought by the payment of wages».

In other words, the search for new truth in economics, as in any pure science, necessitates, in addition to introversive labor, an institutional framework composed of a structure of complementary goods that has been deliberately and rationally constructed by one or more property owners.

The founding members of the Austrian school pursued economic research neither for pecuniary gain nor because they sought professional recognition or an influence on public policy. According to Mises, «When Menger, Böhm-Bawerk and Wieser began their scientific careers [...] [t]hey considered it as their vocation to put economic theory on a sound basis and they dedicated themselves entirely to this cause [emphases are mine]». These three eminent Austrians, therefore, were not economists by profession but by vocation.

The «vocational» economist takes a position in academia or works in some other profession such as banking, journalism, industry or government in order to obtain the concrete means necessary to sustain and complement his efforts to discover new truths or expound and apply established truths in his economic research and writing. 
The "professional» economist, in contrast, aims at earning a livelihood, eliciting acclaim from peers, achieving public fame, shaping political policies or, most likely, a combination of these ends.

Thus the difference between the vocational economist and the professional economist is not their objective method of earning a living but the subjective ends aimed at, which are unobservable. Nonetheless, despite the subjective element involved, the two kinds of economists can be readily distinguished from each other by scrutinizing the disparate views they express toward economic research, particularly its truth content and perceived rewards.

Vocational economists like Murray Rothbard are not allergic to using the unfashionable terms «truth» and «law» when characterizing the science of economics. For Rothbard economics is a substantive body of immutable and universal causal laws that are logically deduced from the incontrovertible fact that people employ means to attain their most desired ends. As such, Rothbard held that «all these elaborated laws [of economics] are absolutely true» and that «economics does furnish [...] existential laws».

Furthermore, in the 1950's and 1960's, Rothbard was working on Austrian economics in obscurity and virtual isolation. He did not obtain a full time academic position until 1966 and, before then, was earning a precarious living on foundation grants while he soldiered on in building up the Austrian theoretical edifice. Yet Rothbard revealed in an interview in 1990 that he had been quite content during this period: "Any chance to write a book or meet new people was terrific». These are the views and the attitudes of the ideal vocational economist. 


\section{THE PROBLEM OF THE PROFESSIONAL}

Paul Samuelson is the exemplar of the modern professional economist. When Samuelson once grandiosely declared, «I can claim in talking about modern economics I am talking about me,» he spoke truer than he knew. In his approach to economic research Samuelson is a self-proclaimed follower of the "views of Ernst Mach and the crude logical positivists».

These so-called philosophers of science contended, «good theories are simply economical descriptions of the complex facts of reality that tolerably well replicate those alreadyobserved or still-to-be-observed facts». Of course economic theory formulated as a shorthand summary of a past sequence of observable and non-repeatable historical facts cannot possibly elucidate the immutable causal laws that operate and interact to produce a unique and complex economic phenomenon at a later moment in history. Nonetheless, Samuelson embraces this view of economic theory: «Not for philosophical reasons but purely out of long experience in doing economics that other people will like and that I myself will like [...] When we are able to give a pleasingly satisfactory ' $\mathrm{HOW}^{\prime}$ for the way of the world, that gives the only approach to 'WHY' that we shall ever attain».

Samuelson and Solow's formulation of the now discredited stable Philip's Curve tradeoff between inflation and unemployment is an example of such Machian theorizing in action. Without doubt, the Philips Curve for a time was well liked by Samuelson, Solow and other professional economists and even used by policymakers, but its truth content in the face of the stagflation that developed in the 1970's was exactly nil.

Ultimately, however, the professional economist need not fret overly much about whether he can harvest a grain of truth from such unrealistic models, because his reward for pursuing economic research lies elsewhere. According to Samuelson, «In 
the long run the economic scholar works for the only coin worth having -our own applause».

Elsewhere, Samuelson described scientists, including professional economists, as being «as avaricious and competitive as Smithian businessmen. The coin they seek is not apples, nuts, and yachts; nor is it coin itself, or power as that term is ordinarily used. Scholars seek fame. The fame they seek [...] is fame with their peers - the other scientists whom they respect and whose respect they strive for».

Samuelson's account of the extroversive reward sought after by modern professional economists clearly - though perhaps unwittingly - reveals that their research endeavors are not governed primarily by a search for truth.

\section{WHY WE MUST CHOOSE}

Mises gives a compelling sociological interpretation of why academic researchers in the aprioristic sciences such as economics and philosophy are diverted from seeking truth to striving after other ends. As universities traditionally developed, the professors were not only supposed to teach but also to make original contributions to their science.

Yet, as Mises noted, very few individuals living during any historical epoch are endowed with such ability. In empirical sciences, whether of the natural or historical variety, however, the illusion that all academic researchers contribute something valuable to their science can be plausibly sustained because there is no visible distinction between the scientific methods employed by the creative genius and those resorted to by the inferior researcher.

As Mises explained:

The great innovator and the simple routinist resort in their investigations to the same technical methods of research. They 
arrange laboratory experiments or collect historical documents. The outward appearance of their work is the same. Their publications refer to the same subjects and problems.

Research in economics is quite different: it requires sustained, rigorous and systematic thinking, a faculty which very few possess and even fewer are willing to exercise. This is true of both the creative genius who constructs a great edifice of economic theory as well as those who seek to refine, extend and apply his system to new problems. His students and followers must also expend many years of their life and a great deal of rigorous mental effort in mastering the entire theoretical system before they can make even minor contributions to economics. Therefore, Mises concluded, in economics:

[T] here is nothing that the routinist can achieve according to a more or less stereotyped pattern. There are no tasks which require the conscientious and painstaking effort of sedulous monographers. There is no empirical research; all must be achieved by the power to reflect, to meditate, and to reason. There is no specialization, as all problems are linked with one another. In dealing with any part of the body of knowledge one deals actually with the whole.

Those aspiring economics professors who lack the intellectual faculties or temperament needed to conduct systematic theoretical research therefore must find another field in which to make their required research contributions. For example, in the Germanlanguage universities of the late nineteenth and early twentieth centuries, these men turned to economic history and descriptive economics. Mises's perceptive sociological analysis explains the rise to dominance and entrenchment of the German historical school in the universities as well as its hysterical antipathy toward economic theory. According to Mises:

The fiction that in the sciences all professors are equal does not tolerate the existence of two types of professors in economics: 
those who work independently in economics [as original theorists]; and those who come from economic history and description. The inferiority complex of these «empiricists» gives them a prejudice against theory.

By the 1920's the German historical school was on its last legs but still ensconced in the professorial chairs. The members of the third generation of the school were a dull and undistinguished lot except for Werner Sombart, who had been a student of Gustav Schmoller's, the leading German historicist of the second generation. Mises, who knew Sombart personally, portrayed him as the quintessential professional economist. It is worthwhile quoting in full Mises's entertaining and eviscerating description of Sombart, because the personality that emerges is the antithesis of the vocational economist:

Werner Sombart was the great master of his set. He was known as a pioneer in economic history, economic theory, and sociology. And he enjoyed a reputation as an independent man, because he had once aroused Kaiser Wilhelm's anger. Professor Sombart really deserved the recognition of his colleagues because to the greatest degree he really combined in his person all their shortcomings. He never knew any ambition other than to draw attention to himself and to make money. His imposing work on modern capitalism is a historical monstrosity. He was always seeking public applause. He wrote paradoxes because he could then count on success. He was highly gifted, but at no time did he endeavor to think and work seriously. Of the occupational disease of German professors - delusions of grandeur- he had acquired an elephantine share. When it was fashionable to be a Marxian, he professed Marxism; when Hitler came to power, he wrote that the Fuehrer receives his orders from God! (Mises 1978, pp. 102-03).

Professionalist aspirations and the culture it engenders are not only inconsistent with truth seeking in economics, however, they are positively antithetical to it. For the professionalization of a scientific discipline, particularly a social science like 
economics, almost always proceeds hand in hand with the expansion of government interventionism.

As Mises put it «The development of a profession of economists is an offshoot of interventionism». The reason for this inevitable connection rests on two facts. On the one hand, the State requires a class of intellectuals and specialists for designing, implementing, and providing rationalizations for various interventions into the market economy. On the other hand, those intellectuals who seek the regular income and prestige that accompany the professionalization of their discipline are ever ready to oblige, because the ability of an intellectual to earn his living researching and writing in his chosen field on the free market is always precarious at best.

As the interventionist State expands, it reinforces the need for trained experts and the university system obtains increasing subsidies from government to initiate and expand graduate programs that will provide such personnel. The lucrative positions in these programs are naturally bestowed on those economists who spearhead the drive to professionalize and are, therefore, most active and outspoken in their support of government interventionism.

In the U.S. the most extreme and thoroughgoing instances of domestic interventionism occurred during the two World Wars of the twentieth century. It was therefore no surprise that the movement to professionalize American economics, which began in the 1880's, experienced quantum leaps during these war crises. For when the State goes to war it needs professional expertise to plan and direct the massive mobilization of the resources it requires. This translates into a cornucopia of lucrative and prestigious jobs for economic experts and specialists in the bureaus and advisory boards of the political planning apparatus that centrally directs the war economy.

In his brilliant book on the professionalization of American economics, Michael Bernstein identifies the central role played 
by World War II in the ultimate success of this movement, perceptively observing:

Under the novel and unrelenting demands posed by national mobilization, modern economic theory had proved its worth [...] Not individualism but rather statism provided the special circumstances within which the high hopes and great expectations of generations of professionalizers could be realized [...] It is one of the great ironies of this history that a discipline renowned for its systematic portrayals of the benefits of unfettered, competitive markets would first demonstrate its unique operability in the completely regulated and controlled economy of total war.

Of course their wartime experience led economists to recognize the potentially great material benefits that would accrue to them from a permanent alliance between their profession and the centralized American State. They responded by formally reorganizing the discipline and reshaping its educational methods and requirements so as to accommodate the prospective needs of the emerging postwar «national security state». Bernstein gives an incisive account of how the American economics profession finally established itself in service to a centralized and interventionist leviathan State:

World War II provided the first systematic demonstration of the beneficence to be won from the largesse of the central government [...] As a matter of course, there emerged a determination to evaluate and reconfigure educational programs in the field, more rigorously stipulate its varieties of expertise and methodologies, and pursue consensus about its central principles and policy orientations. That is to say, that out of the crucible of national mobilization came the beginnings of a professional identity and self-confidence that, while resolutely sought after since the late nineteenth century, had, up to that point, been elusive and fleeting. 
Bernstein goes on to identify some of the arcane subdisciplines within professionalized economics that were developed in response to the needs of the emerging American super-state during the Cold War era which helped to maintain it on a permanent war footing.

The «decision-making sciences» such as linear programming and operations research were developed during World War II to solve the logistical problems associated with supplying overseas troops in different theaters of operation. Game theory was reoriented and refined to assist in the solution of strategic military problems associated with the Cold War conflict - with generous funding from the Department of Defense and especially the Office of Naval Research.

And the development of both mathematical growth theory and the practical application of Keynesian macroeconomics embodied in the Kennedy-era New Economics were in large part stimulated by Cold War concerns. As Bernstein (2001, p. 108) notes with regard to the Keynesian New Economics: "American economists found themselves poised to participate in the realization of some of the most significant statist aims of the cold war era [...] a vigorous national economy was essential both to equip the armed forces and to demonstrate the superiority of American capitalism».

The remarkable proliferation of hyper-specialized fields that occurred during and after World War II led to a disintegration of economic theory, signified by the disappearance of the general economic treatise. No longer was there an integrated system of general economic principles that was held in common and applied to the analysis of all policies and problems by those who called themselves economists. Now each sub-field of research had its own special theory which was more or less sealed off from general economic theory. Even general theory itself was now compartmentalized into microeconomics and macroeconomics. 
This specialization or, more accurately, disintegration of economics compounded by the postwar trend toward a positivist approach to economic theory, whether of the Samuelsonian or Friedmanite variants, destroyed the formidable barrier that had previously confined professional economists with no faculty or vocation for theoretical research to economic history and descriptive economics. They now began to abandon these peripheral areas and to invade what was once the domain of economics proper in droves. Though failing to master the great praxeological system of economic theory that had taken shape in the interwar years, these postwar economists could now undertake research in the splintered, ultra-specialized areas of growth theory, labor economics, industrial organization, oligopoly theory and so on ad infinitum.

However, the unrealistic theoretical models constructed by professional economists then and now can never elucidate the essential laws governing the actual market phenomena associated with their disjointed fields of research. For as Mises pointed out: «The economist must never be a specialist. In dealing with any problem he must always fix his gaze upon the whole system [...] Economics does not allow of any breaking up into special branches. It invariably deals with the interconnectedness of all the phenomena of action».

\section{A FIAT PROFESSION}

Our discussion thus far leads to an important general point. The economics profession is a fiat phenomenon in the same sense as inconvertible paper money. Neither would or could exist on a market free of a specific pattern of government interventions. Government cannot directly command and coerce a newly issued fiat money into circulation in the market economy. Government must first impose a series of interventionist measures such as 
legal tender laws, repeated suspension of convertibility between paper promissory notes and the underlying gold money, the refusal to enforce gold clauses in private contracts, the banning of the private ownership of gold, etc. These interventions distort market processes and prepare the way for the gradual emergence of fiat money.

The same is true of the emergence of the economics profession. Government has no power to directly design and establish a profession with its peculiar and intricately interwoven customs, conventions, research culture, and institutional infrastructure. Nonetheless, a natural vocation like economics can be transformed into a profession as a result of the distortion of market processes and the disturbing of property arrangements caused by wars, political usurpation and subsidization of higher education, and the establishment of centralized bureaus and agencies to implement and oversee economic interventions.

The medical profession is therefore a natural profession that would exist on a free market because it has a natural clientele; the economics profession, along with most other social science professions, is a fiat profession that has no free market clientele and would exist as a truth seeking vocation in the absence of a particular historical pattern of government interventions ${ }^{1}$.

To sum up: the vocational economist strives to master the system of economic theory as handed down by the great system builders and innovators of the past. Once this mastery is achieved, then, depending on his ability, he is poised either to expound and apply this theoretical system, to contribute a few important innovations, or to present a thoroughgoing reformulation that embodies a number of major advances.

There are very few individuals who are capable of successfully embarking on even the first of these paths. Moreover, regardless

${ }^{1}$ I am very grateful to Guido Hülsmann for calling this general implication of my argument to my attention. 
of which path is taken, the vocational economist is driven forward by a thirst for truth which is never slaked. He seeks to know ever more about what Rothbard termed «the structure of reality as embodied in economic law».

Furthermore the extroversive labor he performs for a livelihood, regardless of the field, is merely a means to this and other consumption ends that rank high on his value scale. All other things equal, he is indifferent toward a position in academia except as it provides a more efficient method of pursuing his vocation. Public acclaim and the recognition of his peers, if they come, are not sought after by him but are at most valued byproducts of his activities. Finally, the vocational economist measures progress in his discipline by the quantity and quality of minds that have mastered economic theory, because his own search for truth is facilitated by subjecting his work to the critical evaluation of others pursuing the same calling.

Contrariwise, the professional economist aims, in his research activities, at a number of extroversive ends. These include the approbation of his colleagues, public fame, intellectual influence in shaping government policies, professional advancement and prestige, and, of course, raw power and money. To a great extent, these ends are attainable only with government subsidies and largesse and so he naturally supports an expansive and interventionist state. His natural roosting place, to which he continually returns after his lucrative stints in government service, nonprofit think tanks, and international bureaucracies are the large universities that are subsidized or directly controlled by government. He views progress in economics as a matter of the multiplication of its sub-disciplines and specialized bodies of theory, the increase of the sheer number of bodies in graduate programs, and especially the expansion of opportunities to obtain lucre and positions of power in advising the interventionist, WelfareWarfare State. 
As Mises perceptively noted as early as 1949 , professional economists «rival the legal profession in the supreme conduct of political affairs. The eminent role they play is one of the most characteristic features of our age of interventionism».

\section{REFERENCES}

Bernstein, M.A. (2001), A Perilous Progress: Economists and Public Purpose in Twentieth Century America. Princeton, N.J.: Princeton University Press.

Brown, L. (ed.) (1993), The New Shorter Oxford English Dictionary on Historical Principles, 2 vols. New York: Clarendon Press.

Dolan, E.G. (ed.) (1976), The Foundations of Modern Austrian Economics. Kansas City: Sheed and Ward.

HAYAKAWA, S.I. (1994), Choose the Right Word: A Contemporary Guide for Selecting the Precise Word for Every Situation. $2^{\text {nd }}$ Ed. Eugene Ehrlich. New York: Harper Collins Publishers.

Mises, L. v. (1978), Notes and Recollections. Trans.Hans F. Sennholz. South Holland, Ill.: Libertarian Press.

- [1969] (1984), The Historical Setting of the Austrian School of Economics. Auburn Ala.: Ludwig von Mises Institute.

- (1998), Human Action: A Treatise on Economics. Scholars ed. Ed. Jeffrey M. Herbener, Hans-Hermann Hoppe, and Joseph T. Salerno. Auburn, AL: Ludwig von Mises Institute.

- (1990b), «A Conversation with Murray N. Rothbard». Austrian Economics Newsletter 11 (Summer).

- (2004), Man, Economy, and State: A Treatise on Economic Principles with Power and Market: Government and the Economy. Scholars ed. Auburn, Ala.: Ludwig von Mises Institute.

SALERnO, J.T. (2002), «The Rebirth of Austrian Economics -In Light of Austrian Economics.» The Quarterly Journal of Austrian Economics 5 (Winter): 111-28. 
SAmuelson, P.A. [1949] (1968), «International Factor-Price Equalisation Once Again». In Richard E. Caves and Harry G. Johnson (eds.), Readings in International Economics. Homewood, Ill.: Richard D. Irwin, pp. 58-71.

- [1962] (1970), «Economists and the History of Ideas». In Ingrid H. Rima (ed.), Readings in the History of Economic Theory. New York: Holt, Rinehart and Winston, pp. 282-95.

- (1988), «Economics in My Time». In William Breit and Roger W. Spencer (eds.), Lives of the Laureates: Seven Nobel Economists. Cambridge, MA: The MIT Press, pp. 59-76.

- (1993), «My Life Philosophy: Policy Credos and Working Ways». In Michael Szenberg, Eminent Economists: Their Life Philosophies. New York: Cambridge University Press, pp. 236-47. 